\title{
In Search of Credentials: \\ Factors Affecting Young Adults' Participation in Postsecondary Education *
}

\section{E. DIANNE LOOKER}

Acadia University

\begin{abstract}
This paper uses longitudinal data from a survey of youth in three areas (Hamilton, Halifax and rural Nova Scotia) to examine the factors that affect young adults' participation in postsecondary education, applying Bourdieu's notions of capital and habitus. Data were collected from 1,200 youth in 1989, with questionnaire follow-ups in 1992 and 1994 . The analyses examine (a) the factors the youth themselves say affect their educational decisions and (b) cross-tabulation and regression results that document the variables empirically related to the youth's educational expectations when they are seventeen and their attainments by age twenty-four. Cost factors were found to be a major deterrent as were, for some youth, their knowledge of and attitudes to schooling. Parental education and income affect their children's decisions. University is seen to be "the" preferred postsecondary path; other institutions such as community colleges seem to be the "fall back" option for those who cannot or do not get to university. Results are relevant to an understanding of the persistent impact of parental capital and of one's attitudes on educational outcomes. There are also policy implications regarding the resources needed by different students to better access the postsecondary options available to them.
\end{abstract}

* Funding for this research was primarily provided by the Social Sciences and Humanities Research Council as strategic grants in the area of Education and Work in a Changing Society. 


\section{Résumé}

Ce rapport utilise les données d'une enquête menée auprès de jeunes de trois régions différentes (Hamilton, Halifax et la Nouvelle-Écosse rurale). Il vise à examiner les facteurs qui influent sur la poursuite des études supérieures par les jeunes adultes en appliquant les "principes de revenu et d'usage" de Bourdieu. Les données ont été recueillies auprès de 1200 jeunes en 1989 et complétées par des questionnaires de suivi en 1992 et en 1994.

Les analyses examinent: (a) les facteurs dont les jeunes disent euxmême qu'ils affectent leurs décisions d'orientation; (b) la confrontation et la reconsidération des résultats à la lumière des variantes empiriquement liées aux attentes des jeunes à l'âge de 17 ans et à leurs réalisations à 24 ans. Les facteurs de coût sont apparus comme étant décisifs, tout comme le sont, chez certains jeunes, leur connaissance du système éducatif ainsi que leur attitude vis-à-vis de l'éducation en général. L'éducation et le revenu des parents affectent également les choix de leurs enfants.

L'université apparaît comme la voie royale, en matière d'études supérieures; d'autres institutions, comme les "community colleges" semblent être l'alternative pour ceux qui ne peuvent pas aller ou ne vont tout simplement pas à l'université.

Ces résultats sont à mettre en rapport avec l'influence prépondérante du revenu familial et de l'attitude de chacun vis-à-vis des questions éducatives. On note également une influence politique, en ce qui concerne les fonds dont certains étudiants ont besoin pour mieux accéder à l'enseignement supérieur qui s'offre à eux.

This paper looks at the factors that influence the participation of young adults in postsecondary education. The experience of postsecondary education is important as an educational and social experience in its own right. It is also important by virtue of being a transition that more and more youth experience as they move into adulthood. Indeed, some authors (Dwyer, 1995, 1996; Krahn, 1996) argue that postsecondary education is changing from being "post-compulsory" to becoming defined as expected if not "compulsory" for many young people.' It is also an experience that is complex (see Dwyer, 1996; Krahn, 1995; Looker \& Dwyer, 1996; Thomas, 1993; Wyn, 1996; Wyn \& White, 1997) and which has 
implications for other important transitions, especially the transition to the full-time labour market (Anisef \& Axelrod, 1993; Conference Board of Canada, 1993; Krahn \& Lowe, 1990; Osberg, Wein \& Grude, 1995; Redpath, 1994). Yet, as Krahn, 1996 notes "we know relatively little about the educational motivations of participants in the postsecondary system." (p. 22). Such knowledge is important to both policy and theoretical issues.

\section{Policy Issues}

Completion of some postsecondary education, if not completion of a certificate, diploma or degree program, is becoming defined by more and more employers and educational policy makers as a critical part of the transition to work (Frank, 1996; Gilbert, Barr, Clark, Blue \& Sunter, 1995; Krahn, 1995). Undertaking postsecondary education is seen as improving one's chances for obtaining full-time work (Davies, 1994) and for obtaining access to "better jobs" (Frank, 1996, p. 2), although some researchers note concerns about the unemployment and/or underemployment of university and community college graduates (Anisef, Ashbury \& Bischoping, 1996; Burman, 1988; Krahn, 1991, 1995; Tanner, Krahn \& Hartnagel, 1995). This emphasis on postsecondary education reflects some macro level shifts that have taken place in Canada and other western industrialized nations.

In the 1960 s and 1970 s issues of equity and accessibility were emphasized in Canadian research on postsecondary education. Added to these issues were concerns about the "ability of the education system to produce enough highly skilled graduates" (Krahn, 1995, p. 11). The economy was booming and there was strong public support for government spending on education. In the 1980s and 1990s we see a shift as recession after recession hits, the public mood shifts and governments cut funding to universities and other postsecondary institutions (Axelrod, 1982; Pannu, Schurgurensky \& Plumb, 1994). New emphasis is placed on efficiency and on global competitiveness, rather than on equity and accessibility (Krahn, 1995; Gilbert, et al., 1995). Despite a shrinking and changing full-time labour force, graduates of postsecondary institutions still face a relative advantage over other members of their cohort who have less formal schooling, in terms of accessing the jobs (and the jobs defined as "good" jobs) that remain after this restructuring. Certainly both youth and their parents maintain their commitment to the pursuit of 
"higher" education (Looker, 1994). With fewer government dollars going to the support of various forms of postsecondary education and with correspondingly higher tuition fees there is increasing concern about potential and actual drops in enrollment in certain postsecondary programs.

Overall, two types of policy issues emerge in the current debate about who pursues postsecondary education. One involves a re-emergence of the concerns about equity and accessibility. If the costs associated with certain programs rise while the security of the economic returns for that cost decline, the answer to the question "who goes?" will change in ways that impact differently on different groups. Secondly, there is the issue of what type of postsecondary education programs are in demand by which groups of youth. The traditional research focus on university education is being challenged as more attention and more policy dollars are funneled into other types of postsecondary programs. These constitute important policy issues that can only be addressed once we have a clearer picture of who goes to postsecondary institutions, how this decision varies by social location and why different groups of youth attend or avoid these institutions.

\section{Theoretical Issues}

Beyond these policy issues there are more theoretically driven questions that this paper seeks to address. Bourdieu $(1973,1986)$ outlines the importance of access to various forms of social and cultural capital for the creation and maintenance of class privilege. Parents with high levels of education provide cultural capital through exposure to what he calls "high" culture - museums, art exhibitions, live theater, classical music. Even more importantly, such parents socialize their children to the world view that values these experiences and to knowledge of the language and related skills that allow the appropriation of such cultural events. Command of this world view and these skills can advantage children as they move through the middle class world of the school. In terms of social capital, parents can smooth the way for their children through their networks of connections, through sets of reciprocal obligations, as well as through knowledge of how educational institutions work. The expectation is that these cultural and social as well as (more traditionally researched) economic resources are likely to influence educational outcomes. But it is not simply a matter of parents having resources. They and their children must use these resources; they must exercise their 
agency and "invest" the available capital if they are to have an impact on the child's educational attainments (see Looker, 1994).

Bourdieu also introduces the concept of "habitus", defined as a set of dispositions which (1) organize action, (2) characterize an habitual state, and (3) reflect a predisposition or propensity (Andres Bellamy, 1994, p. 125). Andres Bellamy explicitly points to ways in which both habitus and access to capital influence educational decision making. The concept of habitus highlights the importance of subjective definitions of the situation. Pursuing a postsecondary educational credential must be seen as a feasible option, potential hurdles must be overcome, assets must be identified as such and put to appropriate use. Information on the youths' perceptions of why they made certain decisions and how they were influenced in these decisions will help us understand the role of habitus.

The theoretical and policy issues merge in their focus on who attends postsecondary institutions and why. In this paper I attempt to address these questions. More specifically I will analyze data from a sample of youth to see (a) the extent and types of postsecondary education they undertake, (b) why the youths say they made the decisions they did, and (c) how these educational experiences differ on the basis of the youths' social location.

\section{Sample and Data Gathering Procedures}

The data to be examined come from a study of twelve hundred youth and their parents undertaken in 1989, 1992 and 1994. The youth were all born in 1971, so they were 17 turning 18 years of age during the time of the first data collection. The sample of youth was drawn from three areas: Hamilton, Ontario, Halifax, Nova Scotia and "rural Nova Scotia" (see Looker, 1993 for details). The analysis will identify differences among the three sample areas, as relevant, but will emphasize the more general patterns which apply across areas. ${ }^{2}$

Hamilton is located in the highly industrialized region of southern Ontario. It is itself very much an industrial city, with a range of industry based businesses, including two major steel plants. In contrast, major sources of employment in Halifax come from the various levels of government (municipal, provincial and federal). In addition to being the provincial capital, Halifax boasts several postsecondary educational institutions. Hamilton is home to one university and a large community college. Being located in southern Ontario it is within commuting distance of several 
other postsecondary institutions. Rural Nova Scotia is more heavily dependent on primary industries than either of the two urban areas. Rural Nova Scotia, especially certain areas of Cape Breton and the south shore, have chronically high levels of unemployment. This unemployment has been exacerbated in recent years by severe cutbacks in the fishery. While there are universities and community colleges close to some of the rural respondents, the majority of them have no direct access to either university or community colleges without leaving their home community.

The recession that was to influence many areas of Canada in the late 1980s had not yet hit Hamilton or Halifax when the first data collection was being undertaken in 1989. Unemployment in both Hamilton and Halifax was about $9 \%$. In this Hamilton reflected the employment scene in much of the region of southern Ontario. Halifax, on the other hand, was an oasis in what some would see as a desert of unemployment. ${ }^{3}$ Being the provincial capital and relying so heavily on government positions, Halifax did not feel the full crunch of the recession until the 1990s when governments at all levels intensified programs of restraint and retrenchment. Since many youth see postsecondary education as the pathway to employability, information about the job market in their area informs our analysis of educational decisions.

Ontario and Nova Scotia also differ in terms of the structure of their educational systems. Ontario has a well established system of community colleges (Colleges of Applied Arts and Technology, "CAATs"). The streaming of courses in secondary schools in Ontario reflect these postsecondary options. "General" level courses were designed to prepare a student for admission to a CAAT, while "advanced" courses were designed for the university bound. In the late 1980s Nova Scotia restructured its existing vocational schools and transformed them into postsecondary Community Colleges. Even though school personnel had been anticipating this change for several years, students interviewed in 1989 would not have exposure to the tradition of attending community colleges that was more established in Ontario. Streaming of courses in Nova Scotia schools reflected a split between those "academic" courses that permitted one to go beyond secondary school (usually but not necessarily to a university) and "general" courses which were designated as precluding postsecondary options. ${ }^{4}$ Finally, it should be noted that, in Ontario, the final year of high school is "grade 13" while in Nova Scotia it is "grade 12." This distinction becomes blurred when one realizes that 
it is number of credits and not grade level that determines eligibility to graduate with a high school completion certificate.

\section{Data Collection}

Names and addresses of youth born in 1971 were obtained from schools and school boards in the sample areas. ${ }^{5}$ The lists included those currently enrolled in school as well as those who had graduated and those who had "dropped out" before completing their high school education. In each area, a random sample of names was chosen. In the spring of 1989 in depth interviews were conducted with twelve hundred youth (four hundred in each of the three sample areas). In addition to the pre-coded questions there were a number of open ended questions in the interviews which asked the youth to explain, in their own words, why they made the decisions they did, who influenced them, and how this influence had an impact on them. ${ }^{6}$ Separate questionnaires allowed the parents to give their aspirations and expectations for their teenage daughter or son. ${ }^{7}$

In 1992 a one page questionnaire was sent to the youth and their parents. Those who had moved were traced, and new addresses obtained, if possible. Respondents gave "yes/no" answers to a series of questions that dealt with the youths' experiences since 1989. The current analysis uses information from this 1992 survey $(\mathrm{N}=1,034)$ dealing with the educational attainments of the youth to that time.

In 1994 the original respondents were again surveyed with information obtained from 812 (a $68 \%$ retention rate over five years). ${ }^{8} \mathrm{~A}$ detailed sixteen page questionnaire asked about their educational, occupational and marital/family histories, their aspirations and their attainments. ${ }^{9}$ The youth (who were now twenty-three or twenty-four years old) were also asked who influenced their educational, occupational and other choices, and what factors they saw as playing an important role.

\section{Educational Aspirations and Attainments}

In the 1989 interview the youth were asked a number of questions about their educational aspirations and expectations. The one used here is the measure of the "highest level" of education they realistically expect to obtain. For much of the analysis the responses were recoded into four categories: (1) less than high school completion, (2) high school, (3) nonuniversity postsecondary education, and (4) university. The question 
wording assumes a hierarchy, with university education being classified as "higher" than other forms of postsecondary education.

The 1992 and 1994 questionnaires both provide measures of the youths' educational attainment to that point. In 1992 the measure used was a straightforward "yes/no" format: have you attended (and/or graduated from) a community college, attended (and/or graduated from) a university, taken an apprenticeship, or taken some other training program beyond high school. In 1994 the respondents were asked the highest level of education they had attained by that point. Given the different question wording, the data from 1992 and 1994 are not, strictly speaking, comparable. The 1994 data underestimates the number who have taken non-university programs, since some of these individuals also took university courses, and are counted with the university students.

\section{Factors Affecting Educational Decisions}

There are two different ways that this analysis will examine the factors that affect the youths' educational decisions. The first will focus on 1994 data from the youths' reports of what was important to these decisions. In the structured questionnaires they were given a list of items and asked to what extent each had influenced their decision about whether or not to participate in postsecondary education since high school.

By looking at the youths' reports of influences we get a picture of the issues that the youth themselves define as important. The assumption is that these young people experience and exercise a sense of agency. They see themselves as making decisions which take into account the resources they see as available to them. Some youth may "self select" themselves out of even considering postsecondary education because they feel it is "not for people like me" (Andres Bellamy, 1994). Others have, for as long as they can remember, assumed that they would go to university. The youth understand many of the barriers that face them, in the form of entrance requirements and costs. They recognise the support - or lack of support - they get from parents, teachers and friends. We will start with an examination of this set of questions that focus on how the youth describe the influences on their educational decisions.

The second part of the analysis will identify questions that can measure the more direct effect of a range of factors on the youths' educational decisions. For example, we can examine the extent to which high school marks or academic stream are related to whether the young person, in 
fact, pursued postsecondary education and whether that education was at a university or some other type of institution. The young people may not be aware of the impact of, for example, where they live, as they have not experienced anything different. Similarly, they may be unaware of the effects of gender or of social class, variables that the research literature has indicated affect educational outcomes (Boyd, Goyder, Jones, McRoberts, Peneo \& Porter, 1985; Campbell, 1983; Guppy, Mikicich, \& Pendkur, 1984; Looker, 1983; Sewell \& Hauser, 1976).

The analysis which follows will examine the extent to which each of these variables is associated with the educational attainments of the youth reported in 1994. The paper will conclude with suggestions for policy action that could facilitate access to appropriate education for the youth of tomorrow.

\section{Findings}

\section{Educational Aspirations and Attainments}

As Table 1 shows, most of the youth expect to pursue some form of postsecondary education or training. Less than fifteen percent say they expect to go no further than high school; only a small minority (5\%) do not expect to complete their high school education. About a quarter see themselves going to a postsecondary institution other than a university. Almost two-thirds $(61 \%)$ expect to get some university education, either right after high school, or at some later date.

If we look at the right hand section of Table 1 we see that the youths' actual attainments by 1992 and 1994 are somewhat lower than these "realistic expectations." 10 While a third do obtain some non-university training by 1992 , only $50 \%$ had attended university. By 1994 this figure was $54 \%$. Other analyses show that a third of the youth had a university degree by 1994 .

These expectations and attainments are affected by the social context in which the youth find themselves. Table 1 documents that both gender and sample area influence the educational plans and attainments of these teenagers. There is a tendency for women to have higher aspirations than men. Sixty-six percent of the women compared to $54 \%$ of the men expect to attend university. These differences are consistent with the fact that the females do better in school (see Looker, 1993 for details). What is interesting is that this gender difference reduces to non-significance 


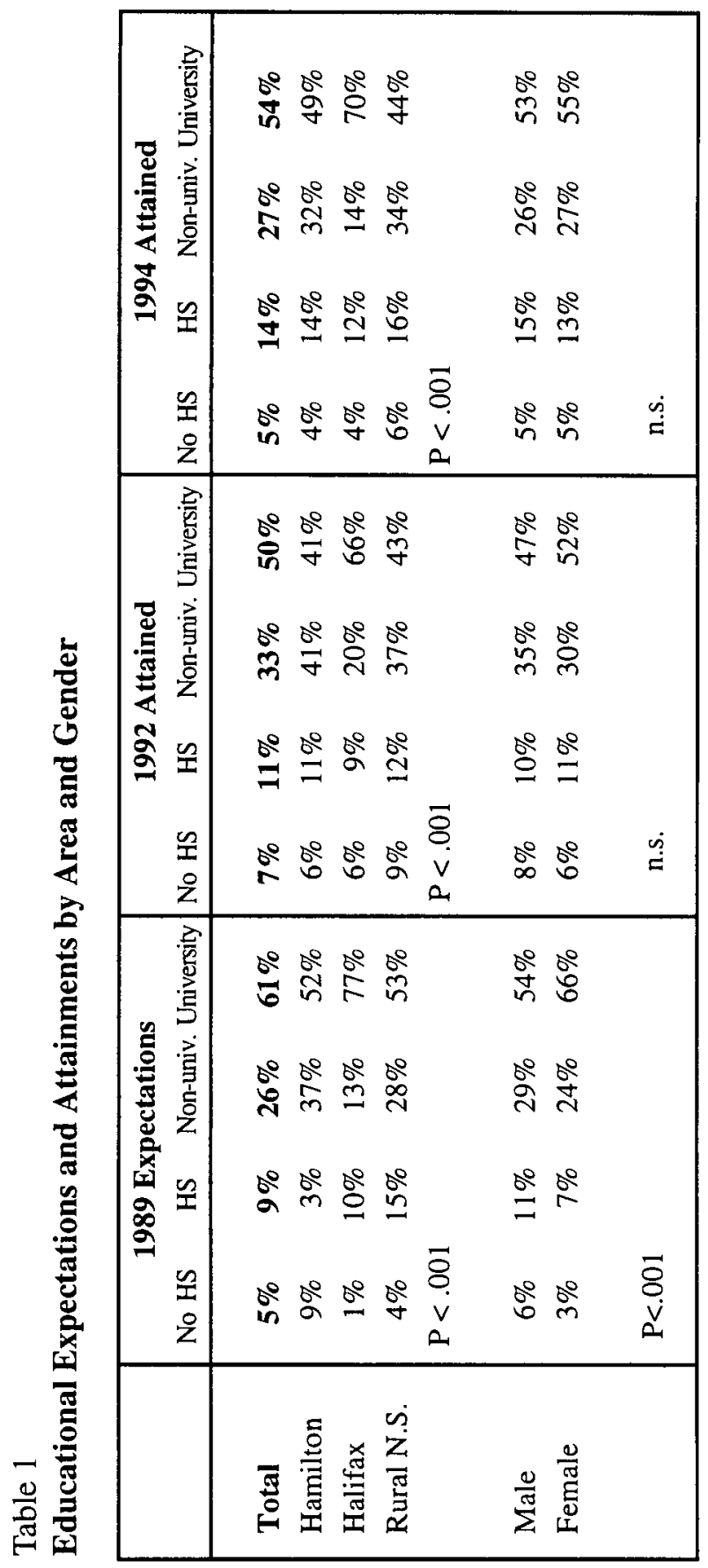

The Canadian Journal of Higber Education

Volume XXVII, Nos. 2, 3, 1997 
when we consider educational attainments - mostly because fewer women manage to attend university."

There is also a rather dramatic difference by sample area. More youth in Halifax than Hamilton or rural Nova Scotia, to expect to attend university ( $77 \%$ compared to $52 \%$ and $53 \%$ ). Many of the Halifax youth, in fact, attain this level of education - 66\% by 1992 and $70 \%$ by 1994 . Fewer youth in Hamilton (49\% in 1994) go to university; even fewer in rural Nova Scotia (44\%). By 1994, $45 \%$ of the Halifax youth and $29 \%$ of the respondents in the other two areas have completed a university degree (data not shown). The difference by sample area is a difference in the type of postsecondary education that is pursued. Very few of the youth in any of the areas stop after high school.

This section highlights the importance of examining the transition to postsecondary education. Less than $20 \%$ of the young adults surveyed in 1994 had no postsecondary experience at all. Close to half (48\%) had not only taken one or more courses but had completed a diploma, certificate or degree program by the time they were twenty four years old. postsecondary education clearly touches a large number of these youth; "postcompulsory" education is the norm. These data also show that a substantial number of those who pursue postsecondary education (between a quarter and a third of all respondents) take the non-university option. The questions then become, what factors differentiate between those who attend, and those who do not pursue any education beyond high school, and what influences their decision about the type of education to pursue.

\section{Youth reports of influences}

The next stage is to look at the factors that the youth themselves see as important to their educational decisions. The youth were asked in 1994 about positive and negative influences in their decision about whether or not to pursue their education beyond high school. Table 2 shows the responses they gave.

The items reported in Table 2 cover a range of influences. One set deals with the youth's school performance and related attitudes. High school marks and courses taken are seen by more than two-thirds of the youth as having a positive influence on their educational decisions. Less than ten percent see these performance issues as having a negative impact. Most positive of all (in terms of the number of respondents) is "attitudes to school;" almost three quarters list these attitudes as having a 


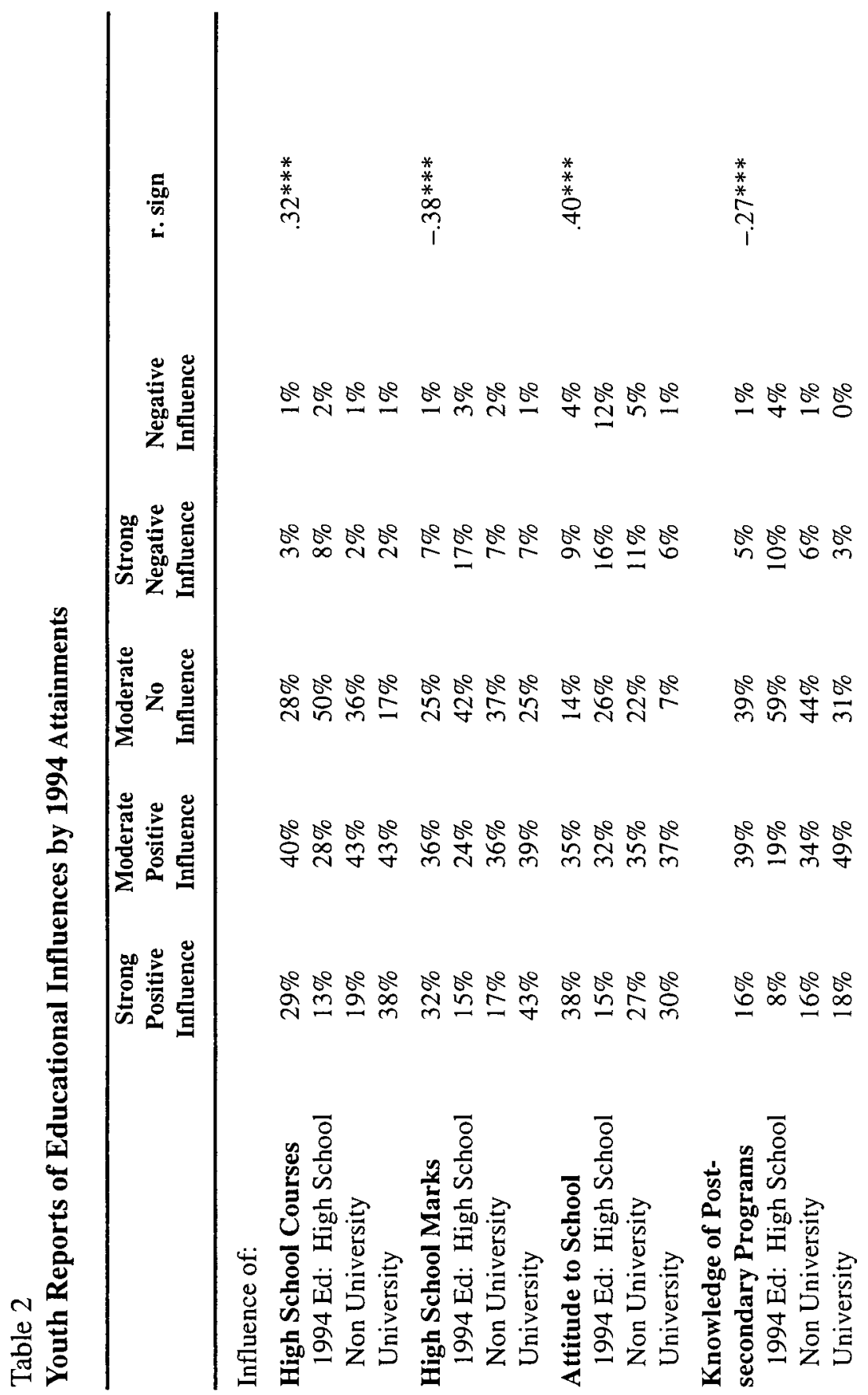

The Canadian Journal of Higher Education

Volume XXVII, Nos. 2, 3, 1997 


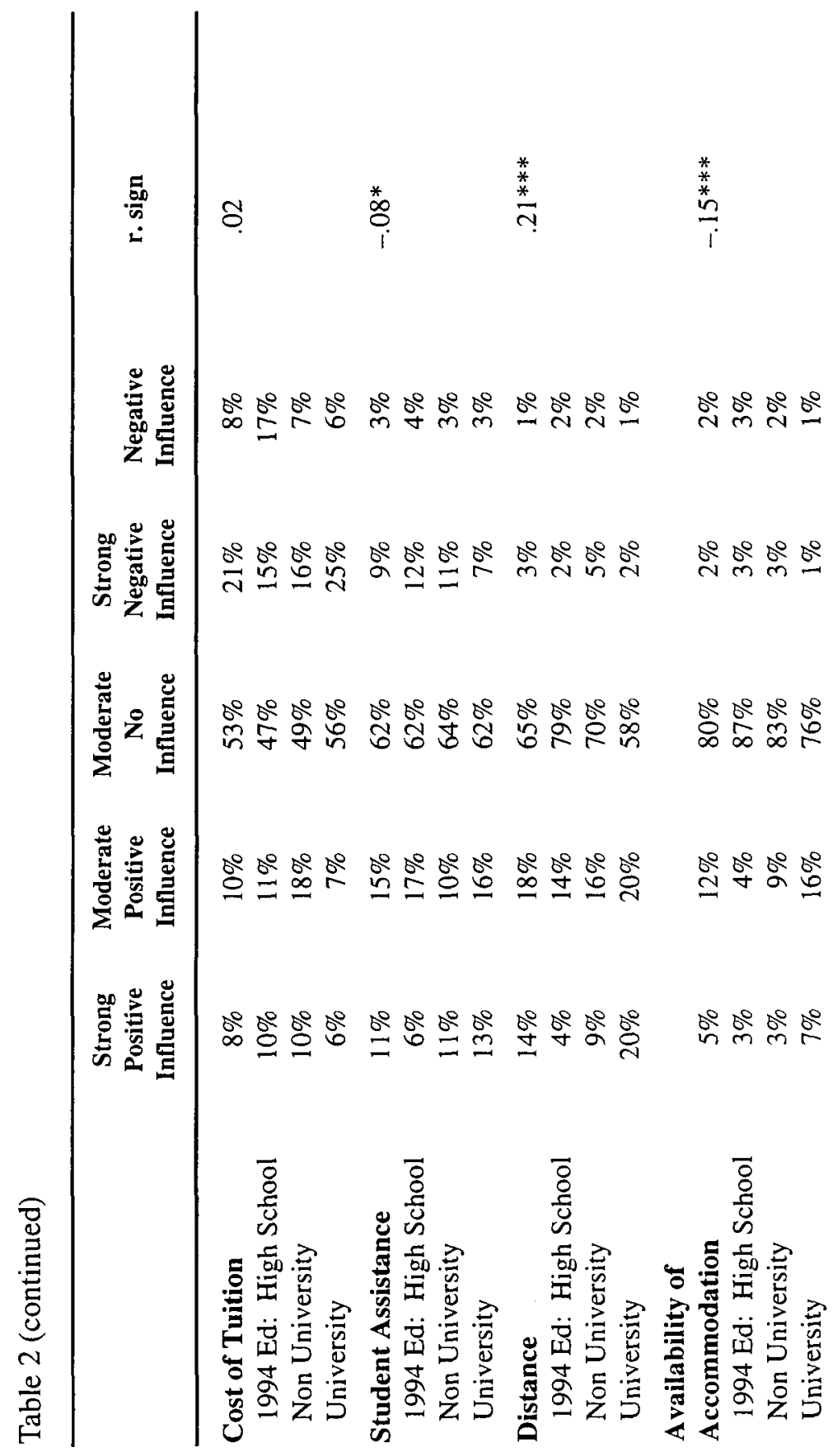

The Canadian Journal of Higher Education Volume XXVII, Nos. 2, 3, 1997 


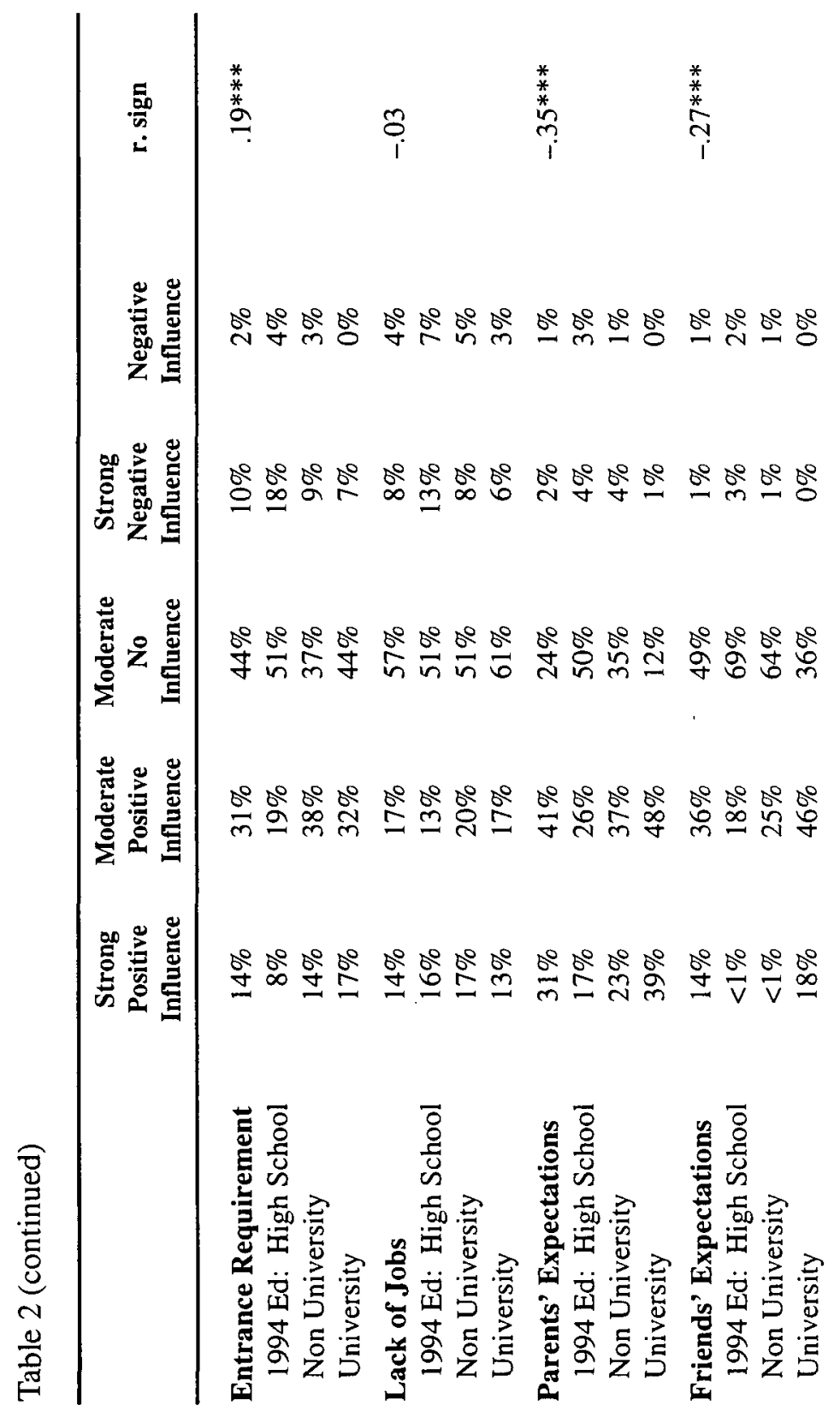

The Canadian Journal of Higher Education

Volume XXVII, Nos. 2, 3, 1997 


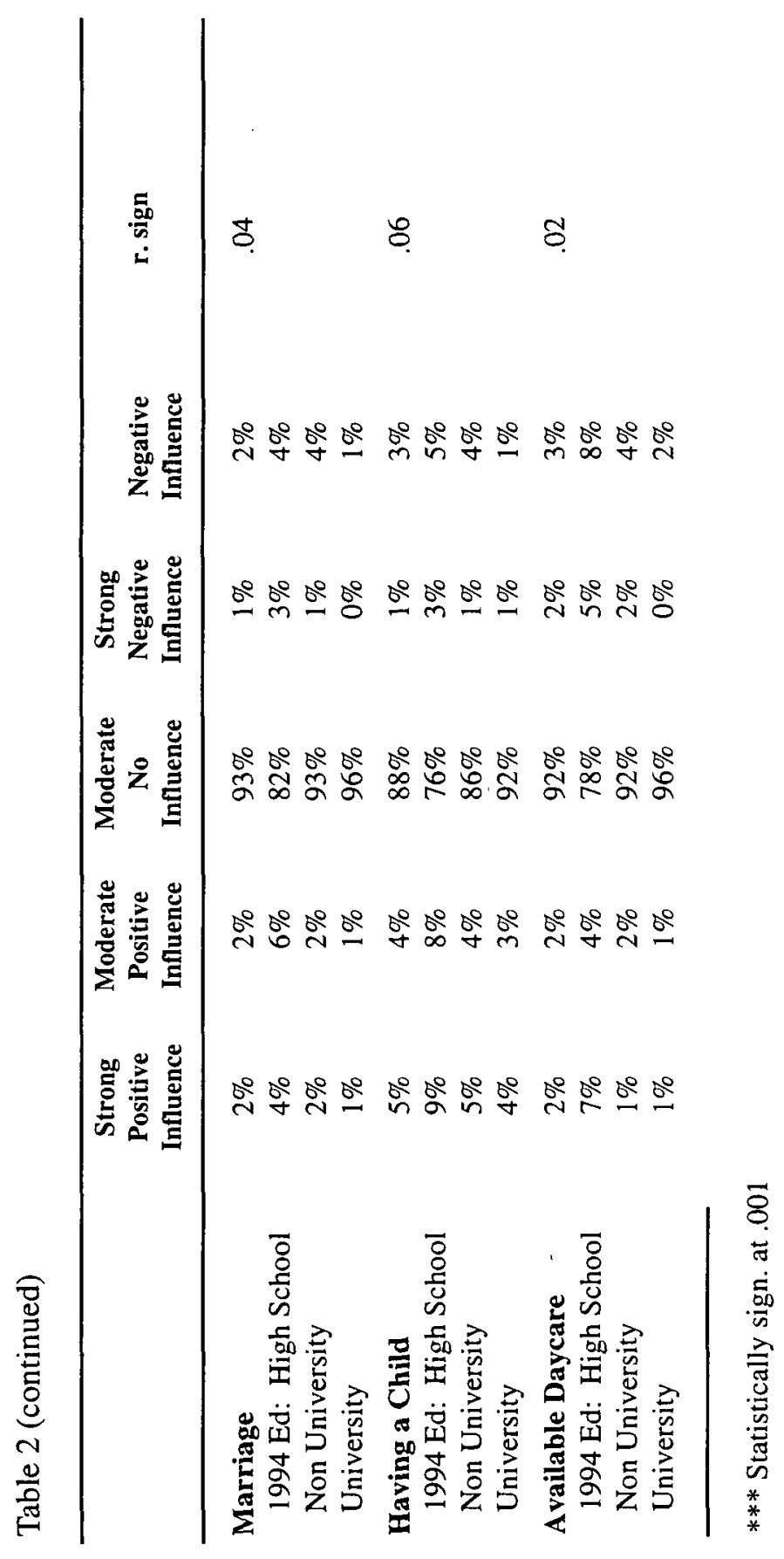

The Canadian Journal of Higher Education Volume XXVI, Nos. 2, 3, 1997 
positive impact. However, this item also has one of the largest numbers (13\%) who see the effect as negative.

School counsellors might be able to shed some light on the sources of counter-productive attitudes. To the extent that negative attitudes keep otherwise qualified students from pursuing their education, it would be important to understand better the origins of these attitudes. Note that marks, courses taken and attitudes all have a more of a positive influence on those who went on to postsecondary, and a more negative impact on those who did not.

Over half say that their "knowledge of postsecondary programs" facilitated their decisions. This knowledge was an asset for those who went on, but much less so for those who stopped after high school. One would expect that all students would have access to appropriate information about postsecondary programs and their prerequisites through school courses and counselling services. In the 1989 interviews less than half of the youth say that their school provided them with counselling that was useful in their educational decisions. By 1994, in retrospect, only a quarter $(27 \%)$ are willing to say that their school helped in this way. It is those who are doing well in school (those with high marks, those in the academic and honours stream), those who are planning to attend university and who are very sure of their plans who are more likely to see the school counselor and more likely to see the counselor often. Their classmates who have failed courses and repeated grades, who have poor marks, who are unsure of what they can do or should do after high school are less likely to turn to the counselor for advice (Looker \& McKinnon, 1996).

Another set of items focus more on attributes of the postsecondary programs - the effects of cost, student assistance, distance, availability of accommodation and entrance requirements. At the top of the list of negative influences, for all the youth, and for both those who did and those who did not attend any postsecondary institution, is the cost of pursuing further education. About a third see the cost of tuition as having a negative impact on them. This issue is particularly relevant in light of recent discussions of increased tuition. As governments cut funding, universities are turning more and more to tuition increases to make up the difference. Access issues take on a new dimension under these circumstances. On a similar note, Table 2 also shows that the lack of student assistance has an impact. While university based financing balances the 
others, there is little assistance available. These two issues, the cost of education and access to funding raise questions about the adequacy of current policies. Higher tuitions, unaccompanied by a restructuring of student assistance, are likely to reduce access to postsecondary education to a range of qualified youth.

Neither distance nor access to accommodation seems to influence many of the youth, although both have a positive impact on the youth who attend universities. Surprisingly, distance has no more impact on rural youth, many of whom live some distance from a postsecondary institution, than it does on urban youth. Many of the rural youth assume they have to leave their home communities, if not for education then for a job. Many opt to move to urban communities where they have relatives, or friends from their home town. They also tend to choose postsecondary institutions that are close enough to "home" that they can return, if not weekly, then for any major holidays or family events. These practices minimize the potential negative impact of distance.

Entrance requirements do have an impact. For many (45\%) they have a positive influence - these would be youth who met the entrance requirements, making postsecondary education a viable option. For a subset (12\% of the 1994 respondents) entrance requirements acted more as a barrier. Not surprisingly, those who went on are more likely to see entrance requirements positively; those who stopped after high school are more likely to say they had a negative impact.

A third set of items focus on other external factors - lack of jobs in the area, and the expectations of parents and friends. The lack of jobs has different effects for the different youth. For some, lack of jobs encouraged them to stay in school (Krahn \& Lowe, 1991, pp. 136-137) - maintaining what is effectively a "holding pattern." For others it is a definite disincentive. As one youth from rural Nova Scotia says:

I have been saddened that I had to leave university . . . I was discouraged at how bleak the chances of getting a job were when I graduated; I watched my friends draw unemployment with their diplomas shoved in a drawer. ${ }^{12}$

Another reinforces this image that an education may not, in fact, be a job ticket. "It is frustrating to get an education then not be able to use it. Being unemployed makes you unable to do anything. You can't get married, buy a house or start your own life. You are in limbo." 
There seems to be widespread acceptance, particularly within the education system, that more education is better than less education. There also seems to be the assumption that access to good jobs requires some level of postsecondary education. However, the link between education and jobs weakens in an economy where many youth are unemployed or underemployed (Anisef, et al., 1996; Davies, et al. 1994; Krahn, 1996). To complete their transitions to adult roles youth need access to jobs that use their skills and training, and that provide a decent livelihood and a reasonable quality of life.

There is little question that these youth are encouraged to continue their education beyond high school. Other data from this same study show that parents, teachers and counsellors are fairly consistent in giving the message to go on. Indeed, most see university as the most appropriate path for all the youth, regardless of the interests or aptitudes of the youth. These expectations do have an impact. The youth themselves cite parental expectations as one of the most common positive influences. It is also the most frequently mentioned positive factor mentioned by those who, by 1994, have been to university. This pattern is consistent with other data (see Looker, 1994; 1995) that confirms the importance of parents and their encouragement of postsecondary education. Friends have a lesser impact, but, on the whole it is a positive one. Half of the youth (two-thirds of those at university) say their friends' expectations positively influenced their educational decisions.

Finally, there are a few items that deal with the impact of marriage and parenting. Only $12 \%$ of the youth $(6 \%$ of the men and $15 \%$ of the women) were married and/or had a child by the time of the 1994 survey. This twelve percent is the base number who could, realistically, be affected by marriage or child bearing. For close to ninety percent of the youth, these issues have little impact at this stage. It will be interesting to see, below, if those with spouses or children are more or less likely to pursue postsecondary education. The qualitative responses from 1989 suggest that marriage and or parenting pushes young men into the labour force (out of further education). Motherhood tends to constrain the young women who feel they "have to" stay home and look after the baby - an activity many would see as incompatible with full time studies (see Looker, 1993).

This section highlights the importance of external factors in the youths' decisions about how much education to obtain. Cost issues and 
access to student assistance come through as particularly important, as is access to jobs upon graduation. Also relevant, in terms of counselling policies, are student attitudes and access to information about postsecondary programs. The expectations of parents and friends are seen as having a definite impact on those who do go on to postsecondary programs, as are various aspects of the youths' school performance. Together these make up the variables which the youth see as having positive or negative influences on their educational decisions. With the exception of the attributes of postsecondary institution and the questions on marriage and parenting, these variables touch on the key issues that researchers have identified as affecting educational outcomes. These issues encompass school performance, youths' attitudes, cost and access issues, and the expectations of significant others.

\section{Empirical Predictors of Educational Attainment:}

For the next section of the analysis, separate measures of these same types of variables will be examined so we can see the match between the factors that the youth say influence them, and the variables which have an empirical relationship with educational attainment. The data set includes measures of school performance, the youth's attitudes to school, family finances (as an indication of ability to meet costs) and the expectations of parents and friends.

Where possible, the responses from the 1989 rather than from the 1994 survey are used, so as to be clear about time (and therefore causal) order. The exceptions to this are the reports of average marks and the highest grade level of mathematics, science and English courses taken. The questions on English, mathematics and science courses were only asked in 1994. The question about marks was asked in both 1989 and 1994. Although it has the limitations of any retrospective measure, the advantage of the 1994 question is that it has a consistent referent marks on the last report card in high school. In 1989 the youth respondents were in a range of different grades. While most were in their next to last year of high school (grade 11 in Nova Scotia, grade 12 in Ontario), more than a third were in lower grades. Using the 1989 question would give information on this range of grade levels.

Table 3 shows the breakdown of each of the relevant variables by 1994 educational attainment levels. All of the identified variables have a statistically significant relationship with educational outcomes in 1994. 


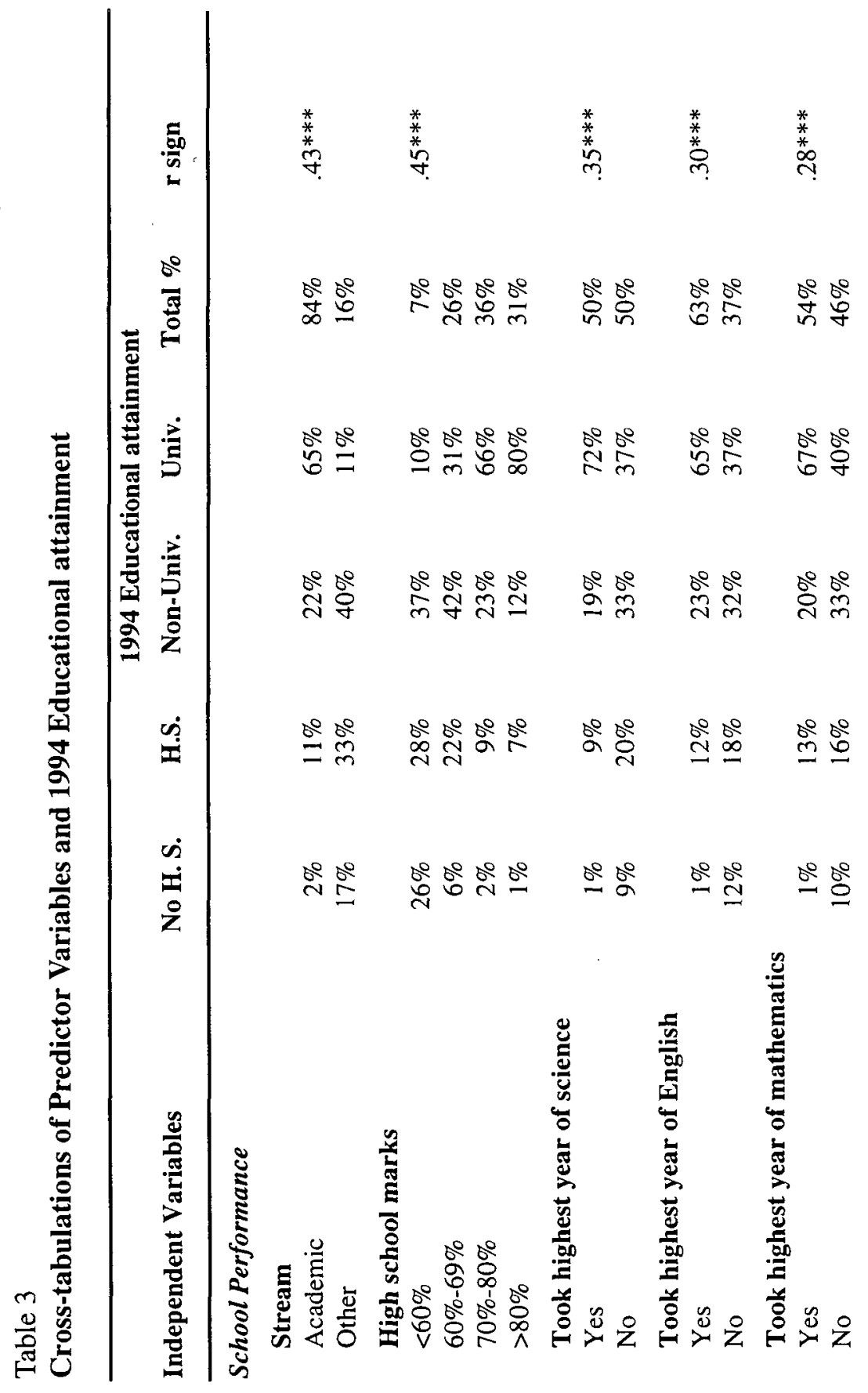

The Canadian Journal of Higher Education

Volume XXVII, Nos. 2, 3, 1997 


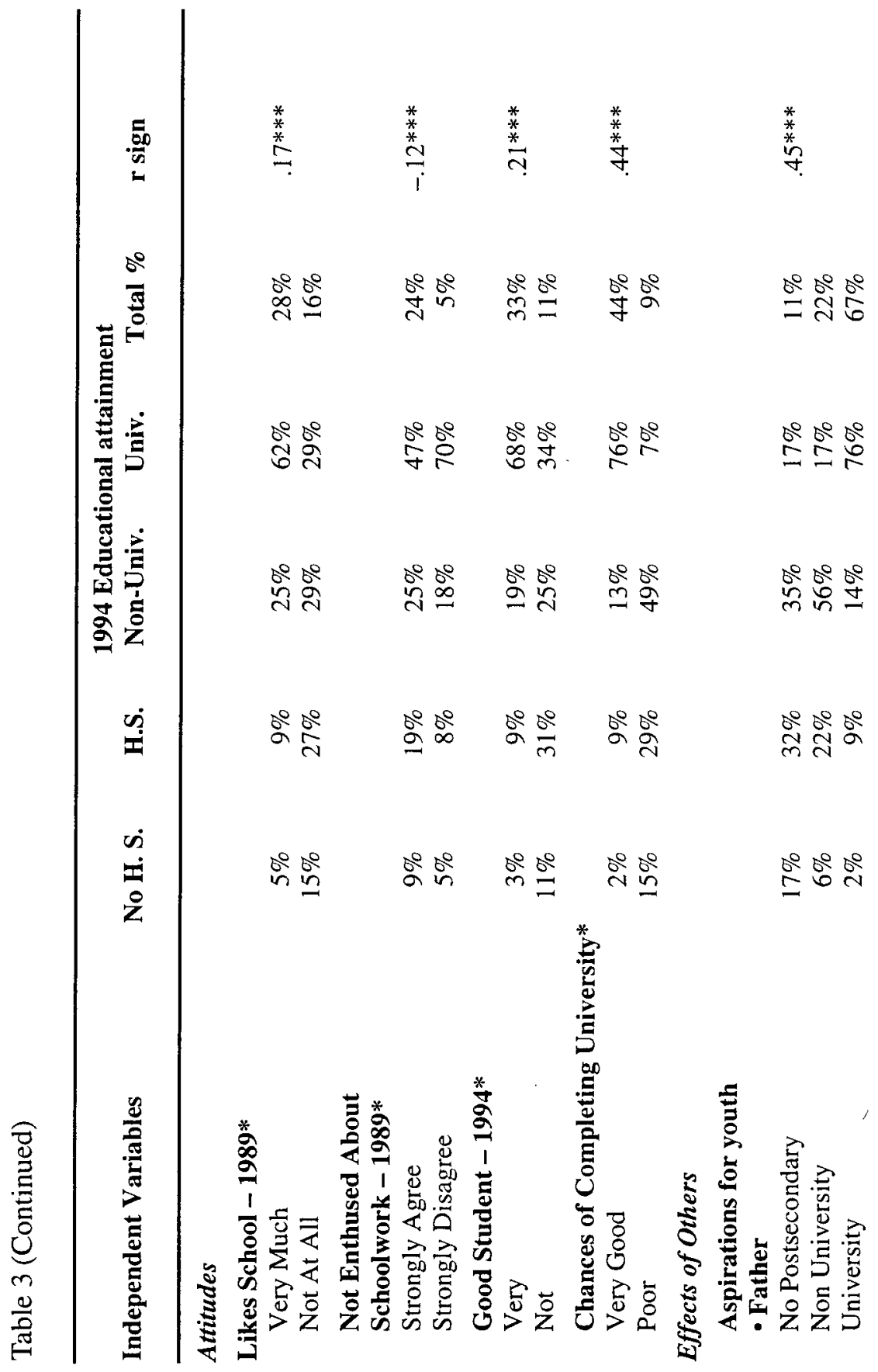




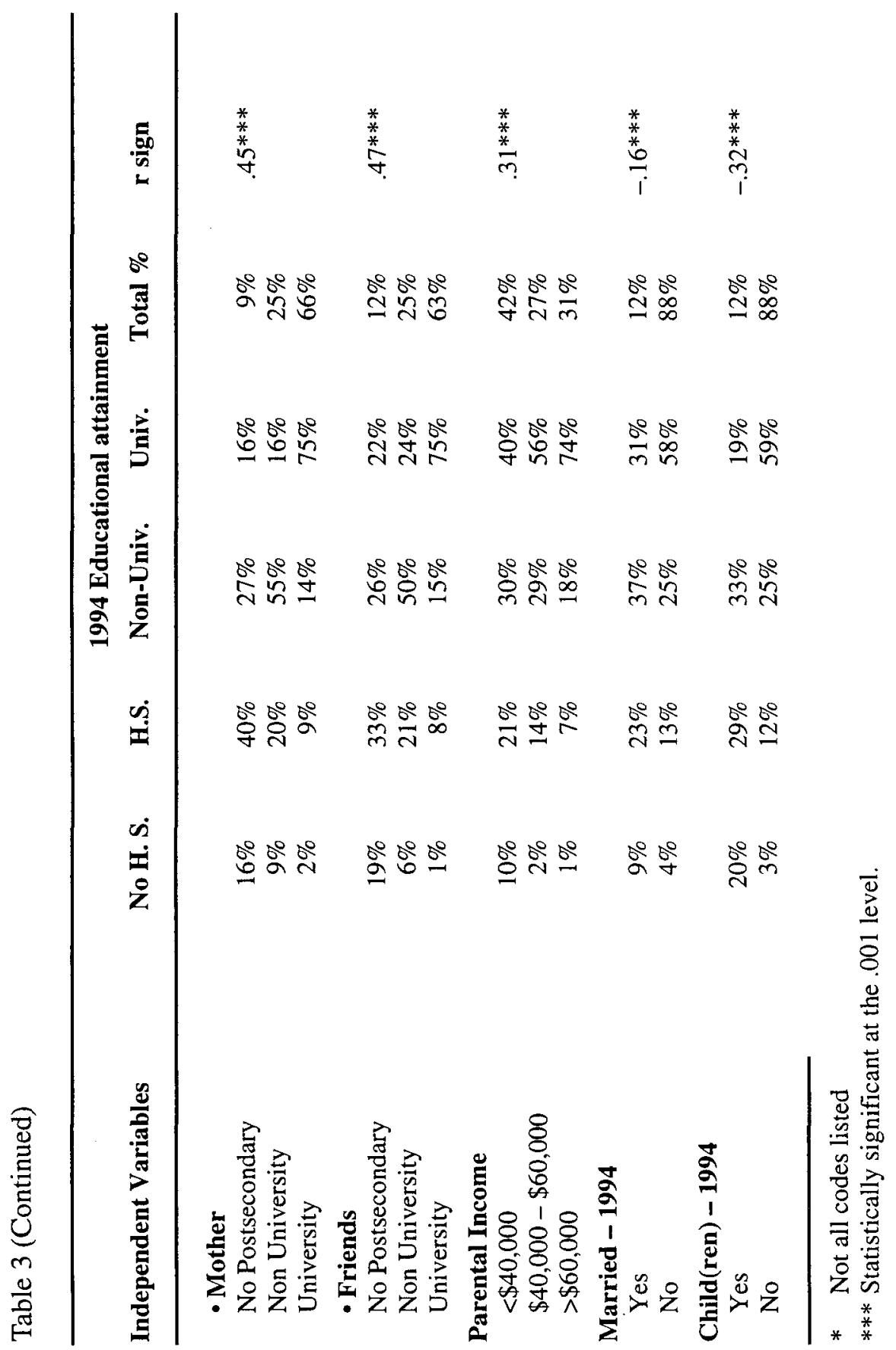


The first set are variables that reflect student performance in school. The ones used are the academic "stream" the student was registered in as of 1989 (recoded to academic/advanced versus other) and the 1994 report of the student's marks on the last report card received in high school. Self-reported marks are not as accurate as actual grade sheets; in the absence of access to official records, this admittedly limited proxy report is the only measure available. There is also the set of questions on the level of English, mathematics and science courses, coded to indicate whether the student took such a course in their senior year of high school (i.e., in grade 12 in Nova Scotia or grade 13 in Ontario).

The majority (84\%) of the youth were in an academic or advanced "stream" - that is they were taking courses that either prepared them for university or, minimally, did not preclude a range of postsecondary options. Not surprisingly, those in courses designed to prepare them for a university programme were more likely than those in other types of courses to attend a university (65\% versus $11 \%$ ). Those in "other" streams were more likely to go no further than high school (33\% versus $11 \%)$, to stop before completing high school, (17\% versus $2 \%$ ) or to take a non-university programme ( $40 \%$ versus $22 \%$ ).

Overall, a third of the youth report average marks in the $80 \%$ or higher range. Less than $10 \%$ say their average was $60 \%$ or less. These marks are clearly related to educational attainment. Eighty percent of those who make "As" (i.e., their average grade is over $80 \%$ ) have attended university by 1994 , compared to two-thirds of those in the next lowest grade range, and only $10 \%$ of those making " $\mathrm{C}$ minus" $(60 \%)$ or less. The relationship is summarized in the correlation of $.45(\mathrm{p}<.001)$.

Students who took advanced English, mathematics or science courses were more likely than their less advanced colleagues to go to university, and less likely to stop either before or just after completing high school. The correlation coefficients are $.35, .30$ and .28 for level of science, English and mathematics, respectively (all statistically significant at the .001 level).

The next section of Table 3 shows the effects of youths' attitudes to school. The items chosen are the 1989 reports on how much the young person liked school, the statement "I find it difficult to get enthusiastic about school work," self image as a good student and perceptions of the chance of completing a university degree if they tried. The first two are measures of the youth respondents' affective feelings about their 
schooling. The second two are more measures of self-image: whether they see themselves as the type of student who does well in school.

More than a quarter are willing to say they like school very much. However, when asked what they like about school, the qualitative responses show that more mention friends than the academic side of schooling. Those who like school are much more likely than those who do not like school (62\% versus $29 \%)$ to attend university. The other side of this relationship $(\mathrm{r}=.17, \mathrm{p}<.001)$ is seen in the fact that that the who dislike school are less likely to complete high school (15\% versus $5 \%$ ) and more likely to stop their education once they have a high school diploma (27\% versus $9 \%$ ).

The other question on attitudes contained in Table 3 shows a less positive side of student attitudes. A quarter strongly agree that they find it difficult to get enthusiastic about their school work; overall three quarters agree with this negative statement. Only a fifth disagree. But again, these attitudes are related to outcomes $(r=-.12, p<.001)$. Those who disagree - that is, those who have no difficulty getting enthusiastic about school work, are more likely to go on to university. Those who feel more negatively are less likely to pursue postsecondary education.

This lack of enthusiasm does not seem to affect the youths' self images, however. A third (more women than men and more of the Hamilton youth) say they are very much seen as a good student. Only a tenth say they are not a good student. Both the correlation coefficient $(\mathrm{r}=.21, \mathrm{p}<.001)$ and the pattern of the percentages, in Table 3, show that those who describe themselves as a good student in 1989 are more likely to have attended a university by 1994 .

As of 1989, fully half see their chance of completing a university degree (if they tried to get one) as being "very good". This variable shows a very strong relationship $(r=.53, \mathrm{p}<.001)$ to 1994 educational outcomes. Seventy-six percent of those who say they have a good chance of completing a university programme, have undertaken such a programme as of 1994. This figure compares to only $7 \%$ of those who are pessimistic about their chances.

The third section of Table 3 gives the expectations that the mother, father and friends have for the young person (according to the youth reports). The interesting point to note is the consistency in the responses given for friends and parental expectations. Over $60 \%$ of the youth say that their father thinks they should attend university; a similar percentage 
say the same of their mothers and their friends. University is clearly the postsecondary option of choice. Only a quarter see some other form of postsecondary education as the one preferred by parents or friends. A minority ( $9 \%$ to $12 \%$ ) say these others think they should stop after high school. These expectations have a relationship with and, one can assume, an impact on the youth's actual choices. The correlations for these three variables with 1994 educational attainment are all of the same order of magnitude, about .45; all are statistically significant at the .001 or more. Those whose mothers, fathers and/or friends think they should pursue a university education are more likely to have done so by 1994 than those who say their significant others are less ambitious for them.

The data set contains some subjective measures of financial resources - whether the young person feels they could afford to attend university, whether they say their parents saved for their postsecondary education. However, the most direct measure of access to resources that could offset the costs of postsecondary education is parental income. The parents were asked in their 1989 questionnaire to report on their total combined household income in the last year, from all sources. If this information was missing from the parental responses, the youth's report of parental income was used. The responses were recoded so that approximately $30 \%$ fell in each of the three categories: under $\$ 40,000$, between $\$ 40,000$ and $\$ 60,000$, and over $\$ 60,000$. (Halifax parents report higher incomes and rural Nova Scotia parents are more likely to have lower ones).

The young people themselves said that cost factors were major considerations in their decision about how much and what kind of education to pursue beyond high school. Sociologists have for decades argued and documented the impact of parental income on youth outcomes (Anisef, et al., 1980; Anisef \& Okihiro, 1982; Boyd, et al., 1985; Porter, Porter \& Blishen, 1979). The current data provide no exception to this pattern. Seventy-four percent of those whose parents are in the highest income bracket have attended university by 1994 , compared to only $40 \%$ of those whose parents make less than $\$ 40,000$. At the other end of the scale, $10 \%$ of the low income families, compared to $1 \%$ of the high income ones have children who fail to complete high school. The overall correlation between parental income and youth educational attainment is $.31(\mathrm{p}<.001)$.

Finally we see the number of youth who have (a) married and (b) have had a child. More women than men (15\% versus $6 \%$ ) and more rural youth have made one or both of these transitions by 1994 . Overall, these 
youth form a minority; only $12 \%$ have either married or had a child (not always the same individuals). But both marriage and parenthood have an impact on educational decisions, for both men and women. Marriage acts to inhibit university attendance $(r=-.16, \mathrm{p}<.001)$, but parenting has an even stronger effect. Only $19 \%$ of those who, by age 24 have had a child, have attended a university. This figure compares to $59 \%$ who, by that age are still childless.

Overall, Table 3 gives us three key messages. The first is that the youth know whereof they speak. All of the measures that correspond to their subjective reports, as imperfect as many of them are, are correlated with actual educational outcomes. Parental income, parents' and friends' expectations, strong school performance and positive school attitudes are more typical of those who have gone on to university than those who have not. Negative attitudes, little external support, responsibilities for a spouse and/or a child act to inhibit this level of educational endeavor.

Secondly, the key difference for virtually all these variables is found in the difference between attending a university and all other outcomes. The pattern of difference is such that those who attend other types of postsecondary institutions are more similar to those who have not attended any postsecondary programme than they are like those who attend university. For example, those in the non-academic stream are more likely than those in the academic to pursue any one of three routes: stopping before completing high school, stopping after high school, and taking a non-university program. Those who are married or who have a child are similarly more likely than their unmarried or childless counterparts with parental or marriage responsibilities to attend a non-university institution; they are also more likely to decide not to pursue any postsecondary education. In sum, the critical cutoff is "university versus other" in terms of outcomes. This is perhaps understandable given the high degree of consensus among parents and educators that university is the desirable educational outcome. However, this consensus raises some serious policy questions about the appropriateness of encouraging most if not all young people to attempt to get a university degree. There is the question of whether all or most youth are prepared for, and can benefit from university programmes. Beyond this there is the issue of how one can support and credit other postsecondary institutions and programmes so that they are given the status and recognition they deserve. 
Finally, there is the importance of the impact of non-academic variables on outcomes. In addition to the attitudinal variables (youths' attitudes and expectations of others) there is the effect of family financial status. Cost was a factor mentioned by many of the youth as influencing their decisions about postsecondary education. Here we see the persistence of the pattern that "money matters" ( Porter, et al., 1979) .

The zero order correlations reported in Table 3 give an indication of the strength of the relationships between each of these measures and the youth's 1994 educational attainments. All of these relationships are statistically significant at the .001 level, with some being stronger than others. However, many of these variables are related to each other. Only a multivariate analysis can identify the simultaneous effect of several variables, controlling on others.

\section{Multivariate Analyses:}

The final stage of the analysis is to go beyond the bivariate level of relationships to see how these different variables combine to influence the likelihood of the youth pursuing postsecondary options. Given the question wording, this is a hierarchical listing of educational options, so we have an ordinal "level of attainment", with post-graduate education at the top and "less than high school" at the bottom. Using this measure as the dependent variable multiple regression allows us to identify the impact of each of the predictor variables, controlling on the others. ${ }^{13}$

There were three stages in the regression analysis. The first was to combine some of the variables to form a scale in order to get a better overall measure. This procedure was used to create a "parental expectations" measure, formed by adding the scores for father's and mother's expectations. Many youth said both parents agreed they should pursue a university education; these youth would have the highest score. Those who felt neither parent expected them to take any postsecondary had the lowest. Two different measures were created from the school attitude questions. One combined the affective questions about school ("I like school" and "I find it difficult to get enthusiastic about school work"). The second measure taps more into the young person's image of how well they perform in an academic setting: "I am seen as a good student" and "I could successfully complete a university degree if I tried."

The second stage in the procedure was to run a stepwise regression analysis with all the variables listed in Table 3, plus gender, sample 
area and parental education as the independent variables. This resulted in an interim equation, with several variables excluded as they had no statistically significant effect. Finally, the regression analysis was redone, using only those variables which, in stage two, had proved to have a statistically significant effect. Table 4 shows the results.

Three measures of academic performance continue to have an effect: taking at least one type of science course in the highest year of high school, high school marks, and being in the academic/advanced stream. Given that universities tend to select students on the basis of academic performance this relationship is, perhaps, not surprising.

The youths' attitudes, as measured by the combined index of their academic self concept also has a significant effect. Those who say they are seen as being a good student and who see themselves as capable of completing a university degree are more likely to pursue higher education after high school. Their feelings about school and school work have no direct effect on educational outcomes.

The youth respondents tell us that cost factors are important. This influence comes through in the impact of parental income. Even after one takes into account the youths' school performance, their attitudes and parental expectations for them, parental income still has an effect on educational outcomes. Parents, (but not friends) also have an impact through their expectations for the young person. If parents expect you to do well, it seems you live up to their expectations.

Marriage did not have a significant effect on educational attainment once these other variables were taken into account, but parenthood did. Both women and men who were parents were less likely to attend university than their childless counterparts. The fact is that more women than men have made this transition by the age of twenty-four, and women and men turn down educational options for different reasons, according to the qualitative data. But parenthood has a similar outcome for both.

Finally, the regression equation includes one variable not in the original list of items reported in Table 3, parental education. Bourdieu's analysis suggests that there is more to parental capital than economic resources. Parents with high levels of education can advantage their children, whether or not they also have access to financial resources. The results from this regression analysis confirms this point. Even after taking in account the advantages made available by higher parental incomes, youth from families with high parental education are more 
Table 4

Regression Analysis of Factors Affecting 1994 Educational Attainment

\begin{tabular}{lcc}
\hline Independent variables & Beta & Sign. \\
\hline Senior year science & 0.08 & $*$ \\
High School marks & 0.20 & $* * *$ \\
Stream & 0.15 & $* * *$ \\
Attitudes toward school & 0.12 & $* * *$ \\
Parents' expectations & 0.14 & $* * *$ \\
Parental income & 0.11 & $* *$ \\
Mother's education & 0.08 & $* *$ \\
Has a child & -0.15 & \\
R squared & 0.41 & \\
\hline$*$ Sign. at .05 & & \\
$* *$ Sign. at .01 & & \\
$* * *$ Sign. at .001 & & \\
\hline
\end{tabular}

likely to pursue higher education for themselves. In this case mother's but not father's education, ${ }^{14}$ as a measure of parental social class and social capital, influences the educational outcome of the youth.

As we saw in Table 1, there is no gender difference in the pattern of 1994 educational outcomes. Given this fact, it is not surprising that gender does not come through as a differentiating variable in the multivariate analysis. This does not mean that gender has no effect on education, but rather that the measures used here fail to tap the diversities that women and men experience as they move past high school. Nevertheless, for the purpose of the issues being addressed in this analysis, gender has no effect.

In the bivariate analysis Halifax stands out as different from both Hamilton and rural Nova Scotia. This effect disappears in the multi-variate analysis (none of the dummy variables for area have a statistically significant effect). It appears that other variables, such as parental income and education and/or youth attitudes and school performance account for the initial area effect.

To summarize, the multivariate analysis confirms several patterns. The findings support the theoretical view that parental capital, in the form of both finances and education provide a potential advantage for youth. This capital is particularly effective when it translates into higher 
school performance, taking advanced science, being in the academic stream. Both parental and youth attitudes (our measure of Bourdieu's "habitus") also have an effect. But the data also suggest that young adults with children face quite different constraints and prospects than those with no dependents. Educational and other policies need to recognise the diversity of experiences facing youth rather than attempting to devise programs that will be all things to all people.

\section{Conclusions and Recommendations}

Some of the patterns found in this analysis are not new. We have known for some time that parental class affects their children's educational (and occupational) attainments. We know that subjective, social psychological variables play an important role in educational outcomes. What is new is the data from the youth themselves, a documentation of the extent to which they recognise the constraints and supports which surround them. Also important is the comparison of university versus other postsecondary institutions, and the implications of this comparison for postsecondary policy.

There are a number of conclusions that could be drawn from these analyses. The importance of attitudes to schooling and knowledge of programs signals a need for supportive and pro-active counselling. We need counsellors in the high schools to take the initiative in contacting students. Those most in need of counselling (especially those who are unsure what they want to do) are those currently least likely to turn to the school counselling office. There may be little that policy makers can do to change youth attitudes. However, educational policy can recognise that these attitudinal constraints exist, and work around them.

For young men pushed into the labour force by family responsibilities and for young women pushed out of school and paid work by motherhood, distance education may be their only viable recourse if they wish to pursue postsecondary education. The irony is, little or no student assistance is available to those who opt to pursue their postsecondary education through part-time studies and/or distance education.

The fact that so many youth mention the cost of postsecondary education raises questions with respect to financing. How can qualified youth afford postsecondary education - especially if there are restrictions on access to student loans? The part-time and summer jobs that students in the past relied on to fund their further education are becoming more and more difficult to obtain. If one is able to find part-time work 
during the school year, one's academic standing can be affected by work demands. Equity concerns that gained such prominence in the 1970s are likely to re-emerge if cost issues are not addressed.

Job issues come into the picture in another way. As Dwyer (1996) notes, shifts in the occupational structure mean more and more youth face prolonged unemployment and/or underemployment, whether or not they complete postsecondary programmes. He argues that neither the current cohort of youth, nor their powerful, vocal middle class parents are likely to tolerate a situation in which the occupational "payoffs" for their heavy investment in the child's education do not appear. The irony of federalprovincial jurisdictional divisions in Canada creates problems for any policy that attempts to coordinate postsecondary education and job issues. Nevertheless, the high levels of postsecondary participation in Canada, and the high expectations that accompany them will have to be addressed - either by providing appropriate jobs, by encouraging more educated youth to leave the country (assuming there exist other locations with high demands), or by "cooling out" the youth and their parents in some way.

Finally there is the situation of non-university educational institutions. Provincial governments have invested considerable time, energy and money into developing and maintaining these "alternatives to university." Youth who pursue these non-university programmes may well see them as "the better option" (Dwyer et al., 1997). However, these institutions still suffer from the stigma of being "the other." With neither parents nor school officials promoting them, students are unlikely to choose them as their first option. Rather, those who cannot, for some reason, get into university will "end up" in these other institutions, reinforcing their negative image.

The analyses above showed that in most instances the key differences appeared not between those who went on beyond high school and those who didn't but rather between those who went to university and all others. Those with high levels of school performance, strong parental support, positive attitudes and the advantage of higher social class standing go to university; those without these advantages settle for "less." These patterns show the need for better communication of the viability of non-university options to parents, to youth and to educators, particularly school counsellors. We need to seriously question the logic that pushes so many of our young people into universities. The tensions between universities and other institutions are only likely to increase as government funding cutbacks continue and there is increasing competition for students. Governments which are serious 
about promoting community colleges and other non-university programmes will need to address the issue of what these programmes offer youth and their parents.

\section{References}

Andres Bellamy, L. (1994). Capital, habitus, field, and practice: An introduction to the work of Pierre Bourdieu. In L. Erwin \& D. MacLennan (Eds.), Sociology of education in Canada: Critical perspectives on theory, research \& practice (pp. 120-136), Toronto, ON: Copp Clark Longman Ltd.

Anisef, P., Ashbury, F. D., \& Bischoping, K. (1996). Postsecondary education and underemployment in a longitudinal study of Ontario baby boomers. Higher Education Policy, 9(2), 159-174.

Anisef, P., \& Axelrod, P. (1993). Universities, graduates, and the marketplace: Canadian patterns and prospects. In P. Anisef \& P. Axelrod (Eds.), Transitions: Schooling and employment in Canada (pp. 103-114). Toronto, ON: Thompson Educational Publishing Inc.

Anisef, P., \& Okihiro, N. (1982). Losers and winners: The pursuit of equality and social justice in higher education. Toronto, ON: Butterworths.

Anisef, P., Paasche, G., \& Turrittin, A. H. (1980). Is the die cast? Educational achievements and work destinations of Ontario youth. Toronto, ON: Ministry of Colleges and Universities.

Axelrod, P. (1982). Scholars and dollars: Politics, economics, and the universities of Ontario, 1945-1980. Toronto, ON: University of Toronto Press.

Bourdieu, P. (1973). Cultural reproduction and social reproduction. London: Tavistock.

Bourdieu, P. (1986). The forms of capital. In J.C. Richardson (Ed.), Handbook of theory and research in the sociology of education (pp. 241-257). New York: Greenwood Press.

Boyd, M., Goyder, J., Jones, F., McRoberts, H., Pineo, P., \& Porter, J. (1985). Ascriptions and achievement. Toronto, ON: Oxford University Press.

Burman, P. (1988). Killing time, losing ground: Experiences of unemployment. Toronto, ON: Wall \& Thompson.

Canada, C.B.C. (1993). Employability skills profile. Ottawa, ON: C.B.C.

Davies, S. (1994). Cultural theories of class inequality in Canadian education. In L. Erwin \& D. MacLennan (Eds.), Sociology of education in Canada: Critical perspectives on theory, research \& practice (pp. 83-101). Toronto, ON: Copp Clark Longman Ltd.

Dwyer, P.J. (1996). Outside the educational mainstream: Foreclosed options for youth in the 21st century. Paper presented at Acadia University. 
Dwyer, P.J. (1995). Post-compulsory education in Australia and the domination of truth. Journal of Educational Policy, IO(1), 95-105.

Dwyer, P.J. Harwood, A., Pynter, G., \& Tyler. (1997). Participant pathyways and outcomes in vocational education and training: 1992-1995. Melbourne, Australia: Youth Research Centre, University of Melbourne. (Research Report 14).

Frank, J. (1996, Autumn). After high school: The first years. The first report of the School Leavers Follow-up Survey, 1995. Ottawa, ON: Human Resources Development Canada.

Gilbert, S., Barr, L., Clark, W., Blue, M., \& Sunter, D. (1993, September). Leaving school: Results from a national survey comparing school leavers and high school graduates 18-20 years of age. Ottawa, ON: Prepared under contract to Human Resources Development Canada.

Guppy, N., Mikicich, P., \& Pendkur, R. (1984). Changing patterns of educational inequality in Canada. Canadian Journal of Sociology, 9(3), 319-331.

Krahn, H. (1991). The school to work transition in Canada: New risks and uncertainties. Weinheim: Deutscher Studien Verlag.

Krahn, H. (1995). Non-standard work on the rise. Perspectives on Labour and Income, 7(4), 35-42.

Krahn, H. (1996, March). School-work transitions: Changing patterns and research needs. Discussion Paper prepared for Applied Research Branch Human Resources Development Canada.

Krahn, H., \& Lowe, G.S. (1990). Young workers in the service economy. Economic Council of Canada Working Paper no. 14, Ottawa, ON.

Krahn, H., \& Lowe, G.S. (1991). Transitions to work: Findings from a longitudinal study of high-school and university graduates in three Canadian cities. In D. Ashton \& G.S. Lowe (Eds.), Making their way: Education, training and the labour market in Canada and Britain (pp. 130-170). Toronto, ON: University of Toronto Press.

Looker, E.D. (1995). Transitions to adult life. Paper presented at the Youth 2000 Conference. Middlebrough, England.

Looker, E.D. (1994). Active capital: The impact of parents on youths' educational performance and plans. In L. Erwin \& D. MacLennan (Eds.), Sociology of education in Canada: Critical perspectives on theory, research \& practice (pp. 164-187). Toronto, ON: Copp Clark Longman Ltd.

Looker, E.D. (1993). Interconnected transitions and their costs: Gender and urban/rural differences in the transitions to work. In P. Anisef \& P. Axelrod (Eds.), Transitions: Schooling and employment in Canada (pp. 43-64). Toronto, ON: Thompson Educational Publishing, Inc.

Looker, E.D., Denton, M.A., \& Davis, C.K. (1989). Bridging the gap: Incorporating qualitative data into quantitative analyses. Social Science Research, 18, 313-330. 
Looker, E.D., \& MacKinnon, D. (1996). Looking forward, looking back: Factors affecting the educational decisions of rural youth. Paper presented at the National Conference on Rural Education. Saskatoon, SK.

Looker E.D., \& Pineo, P.C. (1983). Social psychological variables and their relevance to the status attainment of teenagers. American Journal of Sociology, 88(6), 1195-1219.

McGrath, S. (1996). Correlates of postsecondary participation. In B. Galaway \& J. Hudson (Eds.), Youth in transition: Perspectives on research and policy (pp. 189-198). Toronto, ON: Thompson Educational Publishing, Inc.

Osberg, L., Wein, F., \& Grude, J. (1996). Vanishing jobs: Canada's changing workplace. Toronto, ON: Lorimer.

Pannu, R., Schugurensky D., \& Plumb, D. (1994). From the autonomous to the reactive university: Global restructuring and the re-forming of higher education". In L. Erwin \& D. MacLennan (Eds.), Sociology of education in Canada: Critical perspectives on theory, research \& practice (pp. 499-526). Toronto, ON: Copp Clark Longman Ltd.

Porter, M.R., Porter, J., \& Blishen, B. (1979). Does money matter? Prospects for higher education in Ontario. Toronto, ON: MacMillan.

Redpath, L. (1994). Education-job mismatch among Canadian university graduates: Implications for employers and educators. The Canadian Journal of Higher Education, 24(20), 89-114.

Sharp, D.B. (1996). Perceptions of work and education transition problems encountered after high school. In B. Galaway \& J. Hudson (Eds.), Youth in transition: Perspectives on research and policy (pp. 178-188). Toronto, ON: Thompson Educational Publishing, Inc.

Tanner, J., Krahn, H., \& Hartnagel, T.F. (1995). Fractured transitions from school to work: Revisiting the dropout problem. Don Mills, ON: Oxford University Press.

Thomas, A. (1993). Transitions from school to work - and back: A new paradigm. In P. Anisef \& P. Axelrod (Eds.), Transitions: Schooling and employment in Canada (pp. 117-127). Toronto, ON: Thompson Educational Publishing Inc.

Wyn, J. (1996). Taking 'youth' for granted. Paper presented at a mini-conference at the University of Melbourne, Australia, May 31.

Wyn, J., \& White, R. (1997). Rethinking youth. Sydney: Allen and Unwin. 


\section{Notes}

1 In Canada, as of 1995, almost three quarters of twenty-four year olds ( $80 \%$ of high school graduates and $24 \%$ of school leavers) had enrolled in some postsecondary program (Frank, 1996, p. 3).

2 It is important to recognise the limitations as well as the strengths of the sampling design. The inclusion of data from several geographic areas allows an explicit examination of the effects of various contextual factors. Nevertheless, there are many areas of the country not represented in the sample. In broad terms these include: northern Ontario, the West, the North, and Quebec. Youth in both rural and urban regions of these areas may well face different supports and constraints than the youth considered here. Some of the patterns that will be identified are sufficiently clear and consistent across the sampled sites that we can expect them to be replicated in other areas as well; some other patterns may well be more unique to the specific time and places.

3 Data from the 1986 Census indicates that both Hamilton and Halifax had unemployment rates lower than the $10.3 \%$ national rate. The corresponding rate for Nova Scotia that year was $13.5 \%$. Rural Nova Scotia rates are consistently higher than those in the Halifax area - unemployment rates for rural youth are particularly high - as high as $30 \%$ in some areas.

4 It is beyond the scope of this paper to go into all the complexities of the schooling systems in Ontario and Nova Scotia at the times of the surveys. The above description is necessarily an oversimplification; there were a range of courses and programs in both sample areas. Nevertheless, this broad outline highlights the gross differences between the two systems that are likely to influence the issues addressed in this analysis.

5 In Halifax and rural Nova Scotia there was no overlap among school boards. In Hamilton both boards participated - the Hamilton-Wentworth Roman Catholic School Board and the City of Hamilton School Board. Only schools, in either of the two boards, which fell within the municipal boundaries of the city of Hamilton were included in the sampling frame.

6 Responses to these open ended questions were recorded verbatim and transcribed into a separate data file, linked to the precoded numeric data. using a procedure described in Looker, Denton and Davis, 1989.

7 Response rates for those youth eligible and contacted were: Hamilton, $78 \%$, Halifax, $71 \%$, rural Nova Scotia $72 \%$. Adjusting for parent absent homes, the parental response rates were $77 \%$ for mothers and $70 \%$ for fathers, with little variation across sample areas.

8 It is beyond the scope of this paper to do a detailed analysis of the sample attrition. No one group is left out of later surveys, although there are slightly 
more women and slightly fewer of those who, in 1989, were doing poorly in school (low marks, failed a class, had left prior to age seventeen).

9 One hundred and seven of these youth completed only a subset of the 1994 questions.

10 The complexity of the youths' educational paths is shown by the fact that some of them (12\% in 1992) have attended both a university and some other postsecondary program. In 1994, these individuals would be counted only as attending university.

11 Some of the decline in the gender difference over time can be attributed to sample attrition, as more women than men stay in the study; more of those with low educational aspirations drop out.

12 This student also commented "I couldn't get a student loan in my third year. I tried to work full time to pay for school, but then my grades started suffering because I worked late and was too tired to get my schoolwork done." This comment links the issues of costs, student assistance and access to jobs.

13 For this analysis the full range of codes in educational attainments, and in mother's and father's education are used, rather than recoding them to the four codes reported in earlier tables.

14 One must be careful not to over-interpret which parent has an effect in a regression analysis. As is true for parental education, mother's and father's levels tend to be highly correlated. Minor changes in the list of other independent variables can often affect which of the two parental variables comes out as statistically significant. 